\title{
Analisis Keakuratan Capital Asset Pricing Model (CAPM) dan Arbitrage Pricing Theory (APT) dalam Memprediksi Expected Saham pada LQ45
}

\author{
Muhammad Irfan Ibrahim ${ }^{1}$, Jullia Titaley², Tohap K. Manurung ${ }^{3 *}$ \\ 1,2,3 Program Studi Matematika, Fakultas Matematika dan Ilmu Pengetahuan Alam, \\ Universitas Sam Ratulangi Manado \\ *corresponding author email : kris_ton79@yahoo.com
}

\begin{abstract}
Abstrak
Para investor dalam pembelian saham pada dasarnya memiliki tujuan yang sama yaitu mengharapkan pengembalian (return) yang maksimal dan risiko seminimal mungkin. Untuk mengambil keputusan dalam investasi tersebut dengan memperhatikan harapan investor maka diperlukan prediksi yang akurat. Untuk memilih saham dari Pasar Modal, investor menilai dari expected return yang dihitung dari saham tersebut. Para investor dalam memilih portofolio saham sering dihadapkan dengan berbagai faktor yang relevan dalam mengestimasi expected return. Model yang sering digunakan dalam mengestimasi expected return saham berdasarkan faktor-faktor yang dianggap memengaruhi return saham adalah Capital Asset Pricing Model (CAPM) dan Arbitrage Pricing Theory (APT). CAPM merupakan model untuk menentukan expected return saham pada keadaan equilibrium. APT mengasumsikan bahwa expected return saham dipengaruhi oleh berbagai faktor dalam perekonomian dan industri. Tujuan penelitian ini untuk mengetahui perbandingan tingkat keakuratan CAPM dan APT dalam mengestimasi expected return pada saham-saham yang terdaftar pada LQ45. Penelitian ini menggunakan data close price bulanan saham dengan periode Juni 2011-Juni 2016. Dari hasil penelitian ini, menunjukkan bahwa perbandingan keakuratan dari CAPM dan APT yang dilihat dari nilai Mean Absolute Deviation (MAD) yang memiliki selisih yang sangat kecil. Berdasarkan hasil uji-t Dua Sampel Independen dapat diambil kesimpulan yang menyatakan bahwa tidak terdapat perbedaan yang signifikan antara keakuratan CAPM dan APT dalam mengestimasi expected return saham yang terdaftar pada LQ45.
\end{abstract}

Kata Kunci : CAPM, APT, Expected Return.

\section{Accuracy Analysis of Capital Asset Pricing Model (CAPM) and Arbitrage Pricing Theory (APT) in Predicting The Expected Return of Stocks Listed in $L Q 45$}

\begin{abstract}
Basically in purchasing stock, the investors have the same goal wich is to maximize the return and minimize the risk. To take decisions in such investment, by still noticing the expectations of investors will require an accurate prediction. To select a stocks from the capital market, investors need to assess it from the expected return on that stock. To select a stocks from the capital market, investors need to assess from the expected return on that stock. In selecting the stock portfolio, the investors often faces variety of factors that affect the estimation of the expected return. The models wich are often used to estimate the expected return of stocks based on the affecting factors are Capital Asset Pricing Model (CAPM) and Arbitrage Pricing Theory (APT). CAPM is a model to determine the expected return of the stocks on equilibrium state. APT assumes that the expected return of stocks is influenced by many factors in the economics and industries. The purpose of this research is to compare the accuracy of CAPM and APT in estimating the expected return on stocks listed in LQ45. This research uses monthly data of stocks close price in period June 2011 - June 2016. The results of this research, indicate that the comparison of the accuracy of CAPM and APT are seen by Mean Absolute Deviation (MAD)value, which has a very small difference. Based on the results of the Independent samples $t$ test can be concluded that states that there is no significant difference between the accuracy of CAPM and $A P T$ in estimating the expected return of stocks listed in $L Q 45$.
\end{abstract}

Keywords: CAPM, APT, Expected Return. 


\section{Pendahuluan}

Para investor dalam pembelian saham pada dasarnya memiliki tujuan yang sama yaitu mengharapkan pengembalian (return) yang maksimal dan risiko seminimal mungkin. Untuk mengambil keputusan dalam investasi tersebut dengan memperhatikan harapan investor maka diperlukan prediksi yang akurat. Untuk memilih saham dari pasar modal, investor menilai dari expected return yang dihitung dari saham tersebut. Untuk mengestimasi expected return, model yang sering digunakan yaitu Capital Asset Pricing Model (CAPM) dan Arbitrage Pricing Theory (APT) [1].

Capital Asset Pricing Model (CAPM) diperkenalkan oleh Sharpe pada tahun 1964 dan Lintner pada tahun 1965 yang merupakan model untuk menentukan expected return saham pada keadaan equilibrium. Tingkat keuntungan yang disyaratkan pada keadaan equilibrium oleh pemodal untuk suatu saham akan dipengaruhi oleh risiko saham tersebut [2].

Kemudian Stephen A. Ross pada tahun 1976 merumuskan Arbitrage Pricing Theory (APT) dengan dasar dua kesempatan investasi yang mempunyai karakteristik yang identik sama tidak bisa dijual dengan harga yang berbeda. APT mengasumsikan bahwa expected return dipengaruhi oleh berbagai faktor dalam perekonomian dan industri. Namun, CAPM dan APT berpendapat bahwa adanya hubungan positif antara tingkat pengembalian yang diharapkan dengan risiko [3].

Berdasarkan penjabaran diatas, akan dilakukan penelitian untuk membandingkan tingkat keakuratan CAPM dan APT dalam mengestimasi expected return pada saham-saham yang terdaftar di LQ45 Bursa Efek Indonesia. Indeks LQ45 dipilih sebagai sampel penelitian karena indeks ini mengelompokkan saham-saham yang memiliki tingkat likuiditas yang tinggi. Faktor-faktor yang dipilih sebagai faktor yang memengaruhi harga saham adalah faktor ekonomi secara marko, diantaranya inflasi, kurs USD ke Rupiah, dan harga minyak mentah dunia.

\section{Saham}

Saham adalah bukti penyertaan modal pada sebuah perusahaan, dengan membeli saham suatu perusahaan berarti investor menginvestasikan modal atau dana yang nantinya akan digunakan untuk membiayai operasional perusahaan [4]. Banyak jenis informasi yang mungkin memengaruhi harga saham. Informasi-informasi tersebut diantaranya [3] :

1. Berita tentang keberhasilan riset yang dilakukan perusahaan.

2. Pengumuman pemerintah tentang GNP (Gross National Product)

3. Berita bahwa produk pesaing mengalami gangguan.

4. Penurunan tingkat bunga yang tidak diperkirakan.

5. Penjualan yang meningkat lebih dari yang diharapkan.

6. Dll

\section{Risk}

Risk atau risiko dapat diartikan sebagai kemungkinan terjadinya kerugian yang akan dialami oleh para investor atau ketidakpastian atas return yang akan diterima di waktu yang mendatang [5]. Risiko sering dihubungkan dengan penyimpangan atau deviasi dari outcome yang diterima dengan yang diekspektasi. Van Horne dan Wachowics, Jr. mendefinisikan risiko sebagai variabilitas return terhadap return yang diharapkan. Metode yang digunakan untuk menghitung risiko adalah deviasi standar (Standard Deviation) yang mengukur absolut penyimpangan nilai-nilai yang sudah terjadi dengan nilai ekspektasinya. Risiko dapat dinyatakan sebagai berikut [1].

$$
S t D=\sqrt{\frac{\sum_{t=1}^{n}\left[X_{t}-\bar{X}\right]^{2}}{n-1}}
$$

Dengan,

$$
\begin{array}{ll}
\text { StD } & : \text { standard deviation } \\
X_{i} & : \text { nilai ke-i } \\
E\left(X_{i}\right) & : \text { nilai ekspektasi } \\
n & : \text { jumlah dari observasi }
\end{array}
$$


Risiko dapat dikurangi dengan diversifikasi (memperbanyak saham yang dipilih dalam berinvestasi). Namun, secara diversifikasi, risiko dapat dibagi menjadi 2, yaitu risiko sistematis, yaitu risiko yang selalu ada dan tidak bisa dihilangkan atau dikurangi dengan diversifikasi, dan risiko tidak sistematis, yaitu risiko yang dapat dihilangkan atau dikurangi dengan diversifikasi. Risiko tidak sistematis inilah yang menjadi relevan dalam perhitungan risiko. Risiko inilah yang disebut dengan risiko pasar [3].

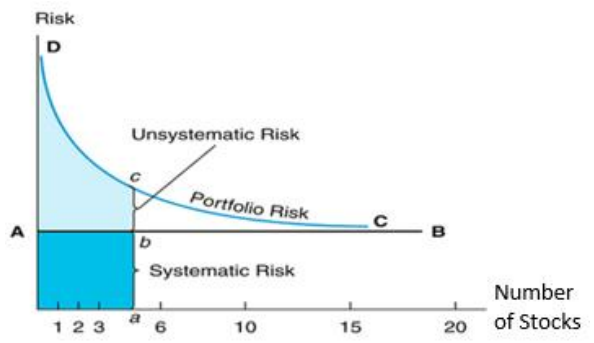

Gambar 1. Grafik pengurangan risiko dengan diversifikasi

\section{Return}

Return merupakan hasil yang diperoleh dari investasi yang dapat berbentuk actual return, yaitu return yang telah terjadi atau excpected return, yaitu return yang diharapkan akan terjadi di waktu yang akan datang [1].

Setiap investasi memiliki risiko, ini menunjukkan bahwa investasi tersebut tidak memberikan return yang pasti. Dalam keadaan seperti ini investor hanya akan mengharapkan untuk memperoleh tingkat keuntungan tertentu. Hal inilah yang disebut dengan expected return. Secara umum expected return dapat dinyatakan sebagai berikut [3].

dimana,

$$
E\left(R_{i}\right)=\sum_{t=1}^{M} P_{i t} R_{i t}
$$

$E\left(R_{i}\right) \quad$ : expected return pada saham ke-i

$P_{i t} \quad$ : probabilitas return saham ke-i pada kejadian ke-t

$R_{i t} \quad$ : return pada saham ke-i pada kejadian ke-t

$M \quad$ : banyaknya kejadian yang mungkin terjadi

Kemungkinan persoalan yang dihadapi bisa saja hanya memperoleh data selama beberapa periode dan tidak dapat memperkirakan probabilitas expected return. Dalam keadaan ini, expected return dihitung dengan membagi jumlah return selama pengamatan dengan jumlah periode.

\section{Beta}

Beta merupakan pengukur risiko sistematik (systematic risk) dari suatu saham atau portofolio terhadap risiko pasar. Jika volatilitas ini diukur dengan kovarian, maka kovarian return antara saham ke-i dengan return pasar adalah sebesar $\sigma_{i M}$. Jika kovarian ini dihubungkan dengan terhadap risiko pasar maka hasil ini akan mengukur risiko saham ke-i terhadap risiko pasar atau disebut dengan beta. Rumus untuk menghitung beta [1]:

$$
\beta_{i}=\frac{\sigma_{i M}}{\sigma^{2}{ }_{M}}
$$

dimana,

$$
\begin{array}{ll}
\beta_{i} & : \text { beta terhadap saham ke-i } \\
\sigma_{i M} & : \text { risiko antara saham ke-i dan pasar } \\
\sigma^{2}{ }_{M} & : \text { risiko pasar }
\end{array}
$$




\section{Capital Asset Pricing Model (CAPM)}

Konsep CAPM pada umumnya berguna untuk mengautentifikasikan hubungan antara risiko dan return. CAPM adalah teori penilaian risiko dan keuntungan aset yang didasarkan koefisien beta (indeks risiko yang tidak dapat didiversifikasi) terhadap pengaruh pasar [6].

Garis yang menunjukkan tradeoff antara risiko dan expected return untuk saham individual disebut dengan Security Market Line (SML). Garis SML ini digunakan untuk menggambar secara grafis dari model CAPM. Hubungan expected return dan beta ini dapat digambarkan pada garis SML [1].

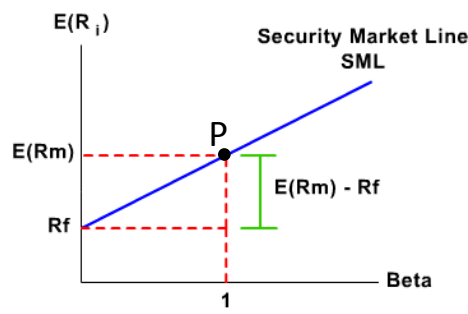

Gambar 2.2. Grafik Security Market Line

Persamaan SML dapat dituliskan menjadi :

dimana,

$$
E\left(R_{i}\right)=R_{f}+\beta_{i}\left[E\left(R_{M}\right)-R_{f}\right]
$$

$E\left(R_{i}\right)$ : expected return pada saham ke-i

$R_{f} \quad$ : return yang bebas risiko

$E\left(R_{M}\right):$ return pasar

$\beta_{i} \quad$ : pengukur risiko saham ke-i

Persamaan (4) inilah yang disebut Capital Asset Pricng Model (CAPM).

\section{Arbitrage Pricing Theory (APT)}

Menurut Ahmad Rodoni dan Othman Young APT sebenarnya adalah berasaskan CAPM, tetapi ia telah mempertimbangkan faktor-faktor lain yang memengaruhi keuntungan saham. Bagi saham ke-i dalam jangka waktu ke-t, keuntungannya dapat diwakili oleh kombinasi antar pengharapan keuntungan seimbang dan faktor-faktor yang memengaruhinya. Untuk saham ke-i, actual return secara formal dapat dinyatakan dengan rumus [5] :

dimana,

$$
R_{i}=E\left(R_{i}\right)+\beta_{1 i} F_{1}++\beta_{2 i} F_{2}+\cdots+\beta_{n i} F_{n}+\varepsilon_{i}
$$

$R_{i} \quad$ : actual return pada saham ke-i

$E\left(R_{i}\right)$ : expected return pada saham ke-i

$\beta_{n i}$ : sensitivitas return faktor ke-n pada saham ke-i

$F_{n} \quad:$ surprise untuk suatu faktor (actual value-expected value)

$\varepsilon_{i} \quad$ : unsystematic risk / risiko spesifik perusahaan, diasumsikan semua kovarian antara return pada saham pada saham terkait dengan efek dari faktor-faktor, sehingga disebut risiko tidak berkorelasi

Dalam model dari APT, beta suatu saham mengukur kepekaan saham tersebut pada faktor tersebut. Karena berdasarkan dua hal ini, yaitu (1) faktor yang memengaruhi tingkat keuntungan, meskipun disebut beta, perlu dibedakan beta dalam lingkup CAPM (menunjukkan sensitivitas terhadap market return) dan beta dalam lingkup APT (menunjukkan sensitivitas terhadap suatu faktor), (2) faktor yang memengaruhi dapat lebih dari satu, maka persamaan APT dapat ditulis [3] :

$$
E\left(R_{i}\right)=R_{f}+\beta_{1 i}\left[E\left(R_{1}\right)-R_{f}\right]+\beta_{2 i}\left[E\left(R_{2}\right)-R_{f}\right]+\cdots+\beta_{n i}\left[E\left(R_{n}\right)-R_{f}\right]
$$

atau dapat ditulis, 
dimana,

$$
E\left(R_{i}\right)=\lambda_{0}+\lambda_{1} b_{1 i}+\lambda_{2} b_{2 i}+\cdots+\lambda_{n} b_{n i}
$$

$$
\begin{array}{ll}
E\left(R_{i}\right) & : \text { expected return pada saham ke-i } \\
R_{f}=\lambda_{0} & \text { : return yang bebas risiko } \\
\beta_{n i}=b_{n i} & : \text { sensitivitas return faktor ke-n pada saham ke-i } \\
\lambda_{n}=\left[E\left(R_{n}\right)-R_{f}\right] & : \text { premi dari faktor ke-n }
\end{array}
$$

\section{Mean Absolute Deviaton (MAD)}

Mean Absolut Deviation adalah nilai yang dihitung dengan mengambil jumlah nilai absolut dari setiap kesalahan prediksi yang dibagi dengan jumlah periode data. Rumus untuk menghitung MAD adalah [1] :

dimana,

$$
M A D=E\left(\left|R_{i t}-E\left(R_{i t}\right)\right|\right)
$$

$R_{i} \quad$ : actual return saham ke-i pada pengamatan ke-t

$E\left(R_{i}\right)$ : expected return saham ke-i pada pengamatan ke-t

\section{Analisis Regresi Sederhana}

Analisis regresi sederhana adalah model regresi dasar yang melibatkan hanya satu variabel bebas dan fungsi regresinya linier. Model analisis regresi sederhana dapat dituliskan [7] :

dalam hal ini,

$$
Y_{i}=\beta_{0}+\beta_{1} X_{1 i}+\varepsilon_{i}
$$

$Y_{i}$ : variabel terikat dalam amatan ke-i

$\beta_{0}:$ intersept $\mathrm{Y}$ pada garis regesi

$\beta_{1}$ : Kemiringan (slope) garis regresi

$X_{1 i}$ : variabel bebas ke-i

$\varepsilon_{i}:$ residual

\section{Analisis Regresi Berganda}

Regresi yang menggunakan lebih dari dua variabel bebas disebut analisis regresi berganda. Model regresi linier umum adalah [8]:

dimana,

$$
Y_{i}=\beta_{0}+\beta_{1} X_{1 i}+\beta_{2} X_{2 i}+\cdots+\beta_{k} X_{k i}+\varepsilon_{i}
$$

$Y_{i} \quad:$ variabel terikat dalam amatan ke-i

$\beta_{0}, \beta_{1}, \ldots, \beta_{k} \quad$ : parameter model

$X_{1 i}, X_{2 i}, \ldots, X_{k i}$ : variabel bebas ke-k dalam amatan ke-i

$\varepsilon_{i} \quad:$ error ke-i

\section{Uji-t Dua Sampel Independen}

Uji-t Dua Sampel Independen (Independent-samples $t$ test) digunakan untuk membandingkan selisih dua rataan (mean) dari dua sampel yang independen dengan asumsi data terdistribusi normal [10].

\section{Metodologi Penelitian}

\subsection{Waktu dan Tempat Penelitian}

Analisis penelitian dilaksanakan selama kurang lebih 2 bulan. Dimulai dari November 2016 hingga Desember 2016. Tempat pelaksanaan analisis data di program studi Matematika, Fakultas Matematika dan Ilmu Pengetahuan Alam Universitas Sam Ratulangi Manado. 


\subsection{Populasi dan Sampel Penelitian}

Populasi yang digunakan pada penelitian ini adalah semua saham yang terdaftar di Bursa Efek Indonesia. saham-saham yang terdaftar di LQ45 menjadi sampel penelitian.

\subsection{Variabel dan Data Penelitian}

Data yang digunakan pada penelitian ini adalah data sekunder, yang diperoleh dari website (dapat dilihat pada tabel 1). Periode data yang digunakan adalah data bulanan selama 5 tahun terakhir, yaitu dari Juni 2011 hingga Juni 2016. Berikut pendeskripsian variabel, data, dan sumber data yang digunakan.

Tabel 1. Deskripsi Variabel Penelitian

\begin{tabular}{|c|c|c|c|c|}
\hline No & Variabel & Deskripsi Data & Rumus & Sumber Data \\
\hline 1. & $\begin{array}{l}\text { Actual return } \\
\left(R_{i}\right)\end{array}$ & $\begin{array}{l}\text { Return dari setiap } \\
\text { saham pada tiap } \\
\text { periode }\end{array}$ & $R_{i}=\frac{r_{t}-r_{t-1}}{r_{t-1}}$ & www.finance.yahoo.com \\
\hline 2. & $\begin{array}{l}\text { Excpected } \\
\text { return }\left(E\left(R_{i}\right)\right)\end{array}$ & $\begin{array}{l}\text { Return yang } \\
\text { diharapkan dari } \\
\text { setiap saham }\end{array}$ & $E\left(R_{i}\right)=\frac{\sum_{i=1}^{n} R_{i}}{n}$ & Hasil perhitungan $R_{i}$ \\
\hline 3. & $\begin{array}{l}\text { Return bebas } \\
\text { risiko }\left(R_{f}\right)\end{array}$ & $\begin{array}{l}\text { Return yang } \\
\text { diperoleh } \\
\text { berdasarkan } \\
\text { penetapan Suku } \\
\text { Bunga SBI }\end{array}$ & $R_{f}=\frac{\overline{X_{S B I}}}{12}$ & www.bi.go.id \\
\hline 4. & $\begin{array}{l}\text { Return Market } \\
\left(R_{M}\right)\end{array}$ & $\begin{array}{l}\text { Return yang } \\
\text { diperoleh } \\
\text { berdasarkan Indeks } \\
\text { LQ45 }\end{array}$ & $R_{M}=\frac{L Q 45_{t}-L Q 45_{t-1}}{L Q 45_{t-1}}$ & $\underline{w w w . f i n a n c e . y a h o o . c o m}$ \\
\hline 5. & $\begin{array}{l}\text { Inflasi } \\
\left(F_{\text {inflasi }}\right)\end{array}$ & $\begin{array}{l}\text { Perubahan tingkat } \\
\text { inflasi dari periode } \\
\text { sebelumnya }\end{array}$ & $\begin{array}{l}F_{\text {inflasi }} \\
=\frac{\text { inflasi }_{t}-\text { inflasi }_{t-1}}{\text { inflasi }_{t-1}}\end{array}$ & www.bi.go.id \\
\hline 6. & $\begin{array}{l}\text { Kurs } \\
\operatorname{USD}\left(F_{\text {kurs }}\right)\end{array}$ & $\begin{array}{l}\text { Perubahan tingat } \\
\text { kurs terhadap USD } \\
\text { dari periode } \\
\text { sebelumnya }\end{array}$ & $F_{k u r s}=\frac{k u r s_{t}-k u r s_{t-1}}{k u r s_{t-1}}$ & www.bi.go.id \\
\hline 7. & $\begin{array}{l}\text { Bahan Bakar } \\
\text { Minyak }\left(F_{B B M}\right)\end{array}$ & $\begin{array}{l}\text { Perubahan tingkat } \\
\text { harga minyak } \\
\text { mentah dari periode } \\
\text { sebelumnya }\end{array}$ & $F_{B B M}=\frac{B B M_{t}-B B M_{t-1}}{B B M_{t-1}}$ & www.investing.com \\
\hline
\end{tabular}

\subsection{Metode Analisis}

1. Pengambilan data-data yang di perlukan dalam penelitian, yaitu close price dari sahamsaham yang terdaftar di LQ45, indkes harga saham LQ45, Suku Bunga Bank Indonesia, data inflasi, Kurs USD terhadap Rupiah, dan harga minyak mentah di Indonesia.

2. Menghitung actual return saham, excpected return saham, return bebas risiko, return market, tingkat inflasi, tingkat kurs USD terhadap Rupiah, dan tingkat perubahan harga minyak mentah.

3. Pendefinisian variabel. Untuk model CAPM variabel terikat adalah actual retun saham, dan variabel bebas adalah return market. Untuk model APT variabel terikat adalah actual return saham, dan variabel bebas adalah tingkat inflasi, tingkat kurs USD ke Rupiah dan tingkat harga minyak mentah dunia.

4. Uji data variabel terikat dan variabel bebas dari kedua model yang digunakan dengan menggunakan Uji Asumsi Klasik untuk membangun model regresi. Uji Asumsi Klasik terdiri dari 4 pengujian, yaitu Normalitas, Heteroskedastisitas, Multikolinieritas, dan Autokorelasi.

5. Jika salah satu Asumsi klasik dilanggar, maka akan melakukan perbaikan data. 
6. Membangun model regresi sederhana untuk CAPM dan model regresi berganda untuk APT berdasarkan variabel yang telah didefinisikan pada langkah ke 2 dan hasil pengujian serta perbaikan pada langkah 4 dan 5 .

7. Menghitung excpected retun dengan CAPM dan APT.

8. Menghitung deviasi dari CAPM dan APT dengan menggunakan Mean Absolute Deviation (MAD).

9. Melakukan uji normalitas pada hasil MAD pada CAPM dan APT.

10. Melakukan uji-t dua sampel independen untuk membandingkan CAPM dan APT dalam memprediksi excpected return.

11. Menarik kesimpulan.

\section{Hasil dan Pembahasan}

\subsection{Objek Penelitian}

Objek penelitian menggunakan daftar perusahaan yang tergabung dalam Indeks LQ45 pada periode Kapitalisasi Pasar per 26 juli 2016.

Tabel 2. Saham yang Tergabung dalam Indeks LQ45 (Kapitalisasi Pasar 26 Juli 2016)

\begin{tabular}{|c|c|c|c|c|}
\hline No & Kode & Nama Perusahaan & Tanggal IPO & Status \\
\hline 1 & AALI & Astra Agro Lestari Tbk & December 9, 1997 & Tetap \\
\hline 2 & ADHI & Adhi Karya (Persero) Tbk & March 18, 2004 & Tetap \\
\hline 3 & ADRO & Adaro Energy Tbk & July 16,2008 & Tetap \\
\hline 4 & AKRA & AKR Corporindo Tbk & October 3, 1994 & Tetap \\
\hline 5 & ANTM & Aneka Tambang (Persero) Tbk & November 27, 1997 & Tetap \\
\hline 6 & ASII & Astra International Tbk & April 4, 1990 & Tetap \\
\hline 7 & ASRI & Alam Sutera Realty Tbk & December 18, 2007 & Tetap \\
\hline 8 & BBCA & Bank Central Asia Tbk & May 31,2000 & Tetap \\
\hline 9 & BBNI & Bank Negara Indonesia (Persero) Tbk & November 25,1996 & Tetap \\
\hline 10 & BBRI & Bank Rakyat Indonesia (Persero) Tbk & November 10, 2003 & Tetap \\
\hline 11 & BBTN & Bank Tabungan Negara (Persero) Tbk & December 17, 2009 & Tetap \\
\hline 12 & BMRI & Bank Mandiri (Persero) Tbk & July 14,2003 & Tetap \\
\hline 13 & BMTR & Global Mediacom Tbk & July 17,1995 & Tetap \\
\hline 14 & BSDE & Bumi Serpong Damai Tbk & June 6,2008 & Tetap \\
\hline 15 & CPIN & Charoen Pokphand Indonesia Tbk & March 18, 1991 & Tetap \\
\hline 16 & ELSA & Elnusa Tbk & February 6, 2008 & Baru \\
\hline 17 & GGRM & Gudang Garam Tbk & August 27,1990 & Tetap \\
\hline 18 & HMSP & Hanjaya Mandala Sampoerna Tbk & August 15,1990 & Tetap \\
\hline 19 & ICBP & Indofood CBP Sukses Makmur Tbk & October 7, 2010 & Tetap \\
\hline 20 & INCO & Vale Indonesia Tbk & May 16, 1990 & Tetap \\
\hline 21 & INDF & Indofood Sukses Makmur Tbk & July 14, 1994 & Tetap \\
\hline 22 & INTP & Indocement Tunggal Prakasa Tbk & December 5, 1989 & Tetap \\
\hline 23 & JSMR & Jasa Marga (Persero) Tbk & November, 12, 2007 & Tetap \\
\hline 24 & KLBF & Kalbe Farma Tbk & July 30,1991 & Tetap \\
\hline 25 & LPKR & Lippo Karawaci Tbk & June 28,1996 & Tetap \\
\hline 26 & LPPF & Matahari Department Store Tbk & October 10,1989 & Tetap \\
\hline 27 & LSIP & PP London Sumatera Indonesia Tbk & July 5,1996 & Tetap \\
\hline 28 & MNCN & Media Nusantara Citra Tbk & June 22, 2007 & Tetap \\
\hline 29 & MPPA & Matahari Putra Prima Tbk & December 21, 1992 & Tetap \\
\hline 30 & MYRX & Hanson International Tbk & October 31,1990 & Tetap \\
\hline 31 & PGAS & Perusahaan Gas Negara (Persero) Tbk & December 15,2003 & Tetap \\
\hline 33 & PTPP & Pembangunan Perumahan (Persero) Tbk & February 9, 2010 & Tetap \\
\hline 34 & PWON & Pakuwon Jati Tbk & October 9, 1989 & Tetap \\
\hline 35 & SCMA & Surya Citra Media Tbk & July 16,2002 & Tetap \\
\hline 36 & SILO & Siloam International Hospitals Tbk & September 12, 2013 & Tetap \\
\hline 37 & SMGR & Semen Indonesia (Persero) Tbk & July 8, 1991 & Tetap \\
\hline 38 & SMRA & Summarecon Agung Tbk & May 7, 1990 & Tetap \\
\hline
\end{tabular}




\begin{tabular}{|c|c|c|c|c|}
\hline No & Kode & Nama Perusahaan & Tanggal IPO & Status \\
\hline 39 & SRIL & Sri Rejeki Isman Tbk & June 17,2013 & Tetap \\
\hline 40 & SSMS & Sawit Sumbermas Sarana Tbk & December 12, 2013 & Tetap \\
\hline 41 & TLKM & Telekomunikasi Indonesia (Persero) Tbk & November 14,1995 & Tetap \\
\hline 42 & UNTR & United Tractors Tbk & September 19,1989 & Tetap \\
\hline 43 & UNVR & Unilever Indonesia Tbk & January 11,1982 & Tetap \\
\hline 44 & WIKA & Wijaya Karya (Persero) Tbk & October 29, 2007 & Tetap \\
\hline 45 & WSKT & Waskita Karya (Persero) Tbk & December 19, 2012 & Tetap \\
\hline
\end{tabular}

Berdasarkan Batasan Masalah yang digunakan, perusahaan yang memiliki tanggal IPO (Initial Public Offering) setelah Juni 2011, tidak diikutsertakan sebagai objek penelitian. Saham yang tidak sebagai objek yaitu SILO (Siloam International Hospitals), SRIL (Sri Rejeki Isman), SSMS (Sawit Sumbermas Sarana), dan WSKT (Waskita Karya (Persero)). Sehingga, dari 45 saham Indeks LQ45, diambil 41 Saham sebagai objek penelitian. Saham yang baru tergabung pada indeks LQ45 menyesuaikan dengan nilai indeks LQ45, akan tetapi data histori yang digunakan adalah periode yang sama.

\subsection{Actual return $\left(R_{i}\right)$ Saham LQ45}

Actual return saham dihitung berdasarkan close price bulanan saham yang tergabung pada Indeks LQ45 pada periode Juni 2011 hingga Juni 2016. Untuk menghitung Actual Return digunakan rumus yang tercantum pada tabel 1 (untuk actual return per periode tiap saham terlampir). Rata-rata actual return saham disajikan pada tabel 3 .

Tabel 3. Rata-Rata Actual Return Saham Periode Juni 2011-Juni 2016

\begin{tabular}{|c|c|r|r|c|r|r|r|r|}
\hline $\begin{array}{c}\mathbf{N} \\
\mathbf{o}\end{array}$ & $\begin{array}{c}\text { Kode } \\
\text { Saham }\end{array}$ & $\begin{array}{c}\text { Actual } \\
\text { Return } \\
\left(\boldsymbol{R}_{\boldsymbol{i}}\right)\end{array}$ & No & $\begin{array}{c}\text { Kode } \\
\text { Saham }\end{array}$ & $\begin{array}{c}\text { Actual } \\
\text { Return }\left(\boldsymbol{R}_{\boldsymbol{i}}\right)\end{array}$ & No & $\begin{array}{c}\text { Kode } \\
\text { Saham }\end{array}$ & $\begin{array}{c}\text { Actual } \\
\text { Return }\left(\boldsymbol{R}_{\boldsymbol{i}}\right)\end{array}$ \\
\hline 1 & AALI & -0.0016 & 15 & CPIN & 0.0188 & 29 & MPPA & 0.0121 \\
\hline 2 & ADHI & 0.0342 & 16 & ELSA & 0.0199 & 30 & MYRX & 0.0268 \\
\hline 3 & ADRO & -0.0110 & 17 & GGRM & 0.0083 & 31 & PGAS & -0.0044 \\
\hline 4 & AKRA & 0.0245 & 18 & HMSP & 0.0084 & 32 & PTBA & -0.0091 \\
\hline 5 & ANTM & -0.0046 & 19 & ICBP & 0.0221 & 33 & PTPP & 0.0406 \\
\hline 6 & ASII & -0.0109 & 20 & INCO & -0.0040 & 34 & PWON & 0.0101 \\
\hline 7 & ASRI & 0.0155 & 21 & INDF & 0.0064 & 35 & SCMA & 0.0093 \\
\hline 8 & BBCA & 0.0108 & 22 & INTP & 0.0035 & 36 & SMGR & 0.0028 \\
\hline 9 & BBNI & 0.0084 & 23 & JSMR & 0.0083 & 37 & SMRA & 0.0198 \\
\hline 10 & BBRI & 0.0122 & 24 & KLBF & 0.0021 & 38 & TLKM & 0.0062 \\
\hline 11 & BBTN & 0.0058 & 25 & LPKR & 0.0152 & 39 & UNTR & -0.0055 \\
\hline 12 & BMRI & 0.0077 & 26 & LPPF & 0.0568 & 40 & UNVR & 0.0208 \\
\hline 13 & BMTR & 0.0117 & 27 & LSIP & 0.0014 & 41 & WIKA & 0.0328 \\
\hline 14 & BSDE & 0.0198 & 28 & MNCN & 0.0240 & Rata-Rata & 0.0116 \\
\hline
\end{tabular}

\subsection{Return Bebas Risiko $\left(R_{f}\right)$}

Return bebas risiko dihitung berdasarkan Suku Bunga Indonesia (SBI) yang ditetapkan oleh Bank Indonesia. Suku Bunga digunakan sebagai return yang bebas risiko karena suku bunga merupakan salah satu variabel yang berpengaruh dalam perekonomi, termasuk investasi. Rata-rata SBI selama periode pengamatan sebesar 0.067855. Nilai rata-rata ini dibagi jumlah bulan selama setahun untuk menentukan nilai return bebas risiko sehingga diperoleh 0.005654 atau $0.56 \%$. 


\subsection{Membangun Model CAPM (Capital Asset Pricing Model) dan Model APT (Arbitrage Pricing Theory)}

Model CAPM dan APT dikerjakan dengan model Regresi Linier. Model CAPM akan dibangun dengan menggunakan model Regresi Linier Sederhana, dan Model APT dibangun dengan model Regresi Linier Berganda. Namun, dalam model regresi yang dibangun, dalam kasus ini hanya diambil nilai beta $(\beta)$ dari model regresi yang dibangun. Dalam model CAPM maupun APT, beta $(\beta)$ berperan penting dalam mengestimasi return saham. Nilai beta $(\beta)$ terkadang bisa positif dan negatif. Nilai beta $(\beta)$ positif menunjukkan jika terjadi kenaikan return faktor, maka mengakibatkan kenaikan return saham, begitu pula sebaliknya. Selanjutnya, jika nilai beta $(\beta)$ negatif, ini artinya bahwa setiap kenaikan return faktor, akan mengakibatkan penurunan return saham, begitu pula sebaliknya. Nilai beta $(\beta)$ perusahaan untuk tiap model dapat dilihat pada tabel 4 berikut.

\begin{tabular}{|c|c|c|c|c|c|}
\hline \multirow{2}{*}{ KODE } & \multirow{2}{*}{ NAMA PERUSAHAAN } & \multirow{2}{*}{$\begin{array}{l}\text { CAPM } \\
\beta \text { Pasar }\end{array}$} & \multicolumn{3}{|c|}{ APT } \\
\hline & & & $\beta$ Inflasi & $\beta$ Kurs & B BBM \\
\hline AALI & Astra Agro Lestari Tbk & 0.590 & -0.067 & 0.476 & 0.311 \\
\hline ADHI & Adhi Karya (Persero) Tbk & 0.964 & 0.134 & -3.302 & -0.378 \\
\hline ADRO & Adaro Enerdyatadk4. Beta Faktor untuk Model & CAPMOdiBgM & odel-ARE5 & -0.380 & 0.372 \\
\hline AKRA & AKR Corporindo Tbk & 0.096 & -0.277 & -0.619 & -0.027 \\
\hline$\overline{\text { ANTM }}$ & Aneka Tambang (Persero) Tbk & 0.626 & 0.017 & -0.813 & -0.657 \\
\hline ASII & Astra International Tbk & 0.789 & -0.032 & -0.853 & -0.153 \\
\hline ASRI & Alam Sutera Realty Tbk & 1.090 & -0.022 & -3.065 & 0.075 \\
\hline BBCA & Bank Central Asia Tbk & 0.410 & 0.014 & -0.283 & -0.020 \\
\hline BBNI & Bank Negara Indonesia (Persero) Tbk & 0.790 & -0.016 & -1.263 & -0.065 \\
\hline BBRI & Bank Rakyat Indonesia (Persero) Tbk & 0.856 & -0.023 & -1.228 & -0.022 \\
\hline BBTN & Bank Tabungan Negara (Persero) Tbk & 0.497 & 0.034 & -2.337 & 0.007 \\
\hline BMRI & Bank Mandiri (Persero) Tbk & 0.577 & 0.012 & -1.985 & 0.047 \\
\hline BMTR & Global Mediacom Tbk & 0.639 & -0.225 & -0.999 & 0.082 \\
\hline BSDE & Bumi Serpong Damai Tbk & 0.943 & -0.079 & -2.013 & -0.200 \\
\hline CPIN & Charoen Pokphand Indonesia Tbk & 0.478 & -0.065 & -2.085 & -0.190 \\
\hline$\overline{\overline{\mathrm{ELSA}}}$ & Elnusa Tbk & 0.204 & 0.006 & -1.005 & 0.453 \\
\hline GGRM & Gudang Garam Tbk & 0.216 & -0.112 & -1.196 & -0.109 \\
\hline HMSP & Hanjaya Mandala Sampo & 0.496 & 0.024 & -1.345 & -0.139 \\
\hline ICBP & Indofood CBP Sukses Makmur Tbk & 0.595 & 0.002 & -0.580 & -0.121 \\
\hline INCO & Vale Indonesia Tbk & 0.065 & -0.158 & 0.155 & 0.198 \\
\hline INDF & Indofood Sukses Makmur Tbk & 0.411 & 0.001 & -0.606 & -0.070 \\
\hline INTP & Indocement Tunggal Prakasa Tbk & 0.554 & -0.142 & -1.210 & -0.054 \\
\hline JSMR & Jasa Marga (Persero) Tbk & 0.567 & -0.080 & -0.889 & -0.243 \\
\hline$\overline{\mathrm{KLBF}}$ & Kalbe Farma Tbk & 0.471 & 0.094 & -1.303 & 0.000 \\
\hline LPKR & Lippo Karawaci Tbk & 0.936 & -0.100 & -1.775 & -0.198 \\
\hline$\underline{\mathrm{LPPF}}$ & Matahari Department Store Tbk & 0.646 & -0.033 & -1.494 & -0.128 \\
\hline LSIP & PP London Sumatera Indonesia Tbk & 0.151 & -0.074 & -0.357 & 0.016 \\
\hline MNCN & Media Nusantara Citra Tbk & 0.598 & -0.044 & -1.601 & -0.018 \\
\hline MPPA & Matahari Putra Prima Tbk & 0.944 & -0.003 & -2.955 & -0.053 \\
\hline$\overline{\overline{\text { MYRX }}}$ & Hanson International Tbk & 0.315 & 0.037 & -1.139 & -0.132 \\
\hline$\overline{\mathrm{PGAS}}$ & Perusahaan Gas Negara (Persero) Tbk & 0.591 & 0.031 & -1.480 & 0.060 \\
\hline SCMA & Surya Citra Media Tbk & 0.223 & -0.120 & -0.970 & 0.136 \\
\hline SMGR & Semen Indonesia (Persero) Tbk & 0.760 & -0.115 & -0.758 & -0.009 \\
\hline SMRA & Summarecon Agung Tbk & -0.217 & -0.096 & -3.818 & -0.150 \\
\hline TLKM & Telekomunikasi Indonesia (Persero) Tbk & 0.404 & 0.066 & -0.675 & -0.026 \\
\hline$\overline{\text { UNTR }}$ & United Tractors Tbk & -0.015 & -0.094 & -0.010 & 0.139 \\
\hline$\overline{\mathrm{UNVR}}$ & Unilever Indonesia Tbk & 0.438 & 0.021 & -0.724 & -0.035 \\
\hline WIKA & Wijaya Karya (Persero) Tbk & 0.770 & 0.039 & -1.584 & -0.252 \\
\hline
\end{tabular}

Berdasarkan hasil pada tabel 4, pada model CAPM (Capital Asset Pricing Model), rata-rata beta kurang dari 1 dan bernilai positif. Hal ini menggambarkan bahwa perusahaan-perusahaan yang tergabung dalam Indeks LQ45 merupakan saham defensif, dengan perubahan return pasar akan 
searah dengan perubahan return saham. Jika return pasar naik, maka return saham pun akan naik. Namun ada beberapa perusahaan yang memiliki nilai $\beta>1$, yaitu perusahaan ASII (Alam Sutra Realty Tbk) dan PWON (Pakuwon Jati Tbk). Ini menunjukkan bahwa kedua saham ini merupakan saham agresif. Tetapi, nilai $\beta$ yang tidak jauh dari nilai 1 menggambarkan return saham terhadap saham tidak terlalu lebih besar dengan perubahan return pasar. Nilai $\beta$ yang negatif, yaitu berada pada perusahaan UNTR (United Tractors Tbk), ADRO (Adaro Energy Tbk), dan SMRA (Summarecon Agung Tbk). Ini menunjukkan bahwa ketiga perusahaan ini mendapatkan return saham dari turunnya return pasar. Semakin turun return pasar, semakin naik return saham dari ketiga saham tersebut.

Selanjutnya pada model APT (Arbitrage Pricing Theory), perusahaan dapat digolongkan sebagai saham defensif, karena beta $(\beta)$ tiap faktor pada model APT kurang dari satu $(\beta<1)$. Hal ini menunjukkan bahwa tiap perusahaan defensif terhadap ketiga faktor (inflasi, kurs, dan BBM) tersebut. Nilai rata-rata beta $(\beta)$ bernilai negatif, artinya naiknya return faktor akan menyebabkan penurunan return saham dan begitu pula sebaliknya, namun ada juga beberapa beta $(\beta)$ yang bernilai positif yang menggambarkan perubahan return dari tiap faktor akan mengubah return saham yang searah dengan perubahan return tiap faktor. Dalam hasil analisis, ditemukan adanya satu faktor yang tidak mempengaruhi return saham, yaitu terdapat pada perusahaan KLBF (Kalbe Farma Tbk). Pada beta BBM $\left(\beta_{B B M}\right)$ KLBF nilai beta 0.000 , ini menunjukkan perubahan return harga minyak dunia tidak akan berpengaruh pada return saham KLBF.

\subsection{Expected Return Model CAPM (Capital Asset Pricing Model)}

Hasil perhitungan expected return $\left(E\left(R_{i}\right)\right)$ dengan menggunakan persamman (4) return bebas risiko sebesar 0.00565 dapat dilihat pada tabel 5 .

Tabel 5. Rata-Rata Expected Return $\left(E\left(R_{i}\right)\right)$ CAPM Saham

\begin{tabular}{|c|c|c|c|c|c|c|}
\hline No & $\begin{array}{c}\text { Kode } \\
\text { Perusahaan }\end{array}$ & $\begin{array}{c}\text { actual } \\
\text { return }\left(\boldsymbol{R}_{\boldsymbol{i}}\right)\end{array}$ & $\begin{array}{c}\text { free risk } \\
\left(\boldsymbol{R}_{\boldsymbol{f}}\right)\end{array}$ & $\begin{array}{c}\text { market expected } \\
{\left[\boldsymbol{E}\left(\boldsymbol{R}_{\boldsymbol{m}}\right)\right]}\end{array}$ & $\begin{array}{c}\text { beta terhadap pasar } \\
\left(\boldsymbol{\beta}_{\text {Market }}\right)\end{array}$ & $\begin{array}{c}\text { expected return } \\
{\left[\boldsymbol{E}\left(\boldsymbol{R}_{\boldsymbol{i}}\right)\right] \text { CAPM }}\end{array}$ \\
\hline 1 & AALI & -0.00164 & 0.00565 & 0.00513 & 0.590 & 0.00535 \\
\hline 2 & ADHI & 0.03424 & 0.00565 & 0.00513 & 0.964 & 0.00515 \\
\hline 3 & ADRO & -0.01097 & 0.00565 & 0.00513 & -0.139 & 0.00573 \\
\hline 4 & AKRA & 0.02447 & 0.00565 & 0.00513 & 0.096 & 0.00560 \\
\hline 5 & ANTM & -0.00463 & 0.00565 & 0.00513 & 0.626 & 0.00533 \\
\hline 6 & ASII & -0.01092 & 0.00565 & 0.00513 & 0.789 & 0.00524 \\
\hline 7 & ASRI & 0.01550 & 0.00565 & 0.00513 & 1.090 & 0.00509 \\
\hline 8 & BBCA & 0.01084 & 0.00565 & 0.00513 & 0.410 & 0.00544 \\
\hline 9 & BBNI & 0.00844 & 0.00565 & 0.00513 & 0.790 & 0.00524 \\
\hline 10 & BBRI & 0.01224 & 0.00565 & 0.00513 & 0.856 & 0.00521 \\
\hline 11 & BBTN & 0.00577 & 0.00565 & 0.00513 & 0.497 & 0.00540 \\
\hline 12 & BMRI & 0.00767 & 0.00565 & 0.00513 & 0.577 & 0.00535 \\
\hline 13 & BMTR & 0.01168 & 0.00565 & 0.00513 & 0.639 & 0.00532 \\
\hline 14 & BSDE & 0.01984 & 0.00565 & 0.00513 & 0.943 & 0.00516 \\
\hline 15 & CPIN & 0.01876 & 0.00565 & 0.00513 & 0.478 & 0.00541 \\
\hline 16 & ELSA & 0.01990 & 0.00565 & 0.00513 & 0.204 & 0.00555 \\
\hline 17 & GGRM & 0.00825 & 0.00565 & 0.00513 & 0.216 & 0.00554 \\
\hline 18 & HMSP & 0.00843 & 0.00565 & 0.00513 & 0.496 & 0.00540 \\
\hline 19 & ICBP & 0.02206 & 0.00565 & 0.00513 & 0.595 & 0.00534 \\
\hline 20 & INCO & -0.00401 & 0.00565 & 0.00513 & 0.065 & 0.00562 \\
\hline 21 & INDF & 0.00636 & 0.00565 & 0.00513 & 0.411 & 0.00544 \\
\hline 22 & INTP & 0.00352 & 0.00565 & 0.00513 & 0.554 & 0.00537 \\
\hline 23 & JSMR & 0.00830 & 0.00565 & 0.00513 & 0.567 & 0.00536 \\
\hline 24 & KLBF & 0.00215 & 0.00565 & 0.00513 & 0.471 & 0.00541 \\
\hline 25 & LPKR & 0.01518 & 0.00565 & 0.00513 & 0.936 & 0.00517 \\
\hline 26 & LPPF & 0.05679 & 0.00565 & 0.00513 & 0.646 & 0.00532 \\
\hline 27 & LSIP & 0.00139 & 0.00565 & 0.00513 & 0.151 & 0.00558 \\
\hline 28 & MNCN & 0.02397 & 0.00565 & 0.00513 & 0.598 & 0.00534 \\
\hline 29 & MPPA & 0.01213 & 0.00565 & 0.00513 & 0.944 & 0.00516 \\
\hline
\end{tabular}




\begin{tabular}{|c|c|c|c|c|c|c|}
\hline No & $\begin{array}{c}\text { Kode } \\
\text { Perusahaan }\end{array}$ & $\begin{array}{c}\text { actual } \\
\text { return }\left(\boldsymbol{R}_{\boldsymbol{i}}\right)\end{array}$ & $\begin{array}{c}\text { free risk } \\
\left(\boldsymbol{R}_{\boldsymbol{f}}\right)\end{array}$ & $\begin{array}{c}\text { market expected } \\
{\left[\boldsymbol{E}\left(\boldsymbol{R}_{\boldsymbol{m}}\right)\right]}\end{array}$ & $\begin{array}{c}\text { beta terhadap pasar } \\
\left(\boldsymbol{\beta}_{\text {Market }}\right)\end{array}$ & $\begin{array}{c}\text { expected return } \\
{\left[\boldsymbol{E}\left(\boldsymbol{R}_{\boldsymbol{i}}\right)\right] \text { CAPM }}\end{array}$ \\
\hline 30 & MYRX & 0.02676 & 0.00565 & 0.00513 & 0.315 & 0.00549 \\
\hline 31 & PGAS & -0.00440 & 0.00565 & 0.00513 & 0.591 & 0.00535 \\
\hline 32 & PTBA & -0.00910 & 0.00565 & 0.00513 & 0.250 & 0.00552 \\
\hline 33 & PTPP & 0.04059 & 0.00565 & 0.00513 & 0.933 & 0.00517 \\
\hline 34 & PWON & 0.01012 & 0.00565 & 0.00513 & 1.033 & 0.00512 \\
\hline 35 & SCMA & 0.00930 & 0.00565 & 0.00513 & 0.223 & 0.00554 \\
\hline 36 & SMGR & 0.00275 & 0.00565 & 0.00513 & 0.760 & 0.00526 \\
\hline 37 & SMRA & 0.01978 & 0.00565 & 0.00513 & -0.217 & 0.00577 \\
\hline 38 & TLKM & 0.00622 & 0.00565 & 0.00513 & 0.404 & 0.00544 \\
\hline 39 & UNTR & -0.00549 & 0.00565 & 0.00513 & -0.015 & 0.00566 \\
\hline 40 & UNVR & 0.02077 & 0.00565 & 0.00513 & 0.438 & 0.00543 \\
\hline 41 & WIKA & 0.03277 & 0.00565 & 0.00513 & 0.770 & 0.00525 \\
\hline
\end{tabular}

Saham pada perusahaan AALI, ADRO, ANTM, ASII, INCO, INTP, KLBF, LSIP, PGAS, PTBA, SMGR, dan UNTR memiliki rata-rata actual return $\left(R_{i}\right)$ yang lebih rendah daripada expected returnnya $\left(E\left(R_{i}\right)\right)$. Hal ini akan memberikan return saham yang lebih kecil dari expected return $\left(E\left(R_{i}\right)\right)$. Saham ini kurang cocok untuk dijadikan tempat untuk berinvestasi. sebaliknya, untuk perusahaan selain kedua belas perusahaan yang disebutkan sebelumnya memiliki rata-rata actual return $\left(R_{i}\right)$ yang lebih tinggi daripada expected return-nya $\left(E\left(R_{i}\right)\right)$. Hal ini akan memberikan return saham seminimal mungkin sebesar expected return $\left(E\left(R_{i}\right)\right)$. Saham yang seperti ini lebih cocok untuk dibeli.

\subsection{Expected Return Model APT (Arbitrage Pricing Theory)}

Hasil perhitungan expected return $\left(E\left(R_{i}\right)\right)$ dengan menggunakan persamaan (6) return bebas risiko sebesar 0.00565 dapat dilihat pada tabel 6 .

Tabel 6. Rata-Rata Expected Return $\left(E\left(R_{i}\right)\right)$ APT Saham

\begin{tabular}{|c|c|c|c|c|c|c|c|c|c|c|}
\hline No & $\begin{array}{c}\text { Kode } \\
\text { Perusahaan }\end{array}$ & $\begin{array}{c}\text { actual } \\
\text { return } \\
\left(R_{i}\right)\end{array}$ & $\begin{array}{c}\text { free risk } \\
\left(\boldsymbol{R}_{f}\right)\end{array}$ & $\begin{array}{c}\text { expected } \\
\text { inflasi } \\
\left(E\left(\boldsymbol{R}_{\text {inflasi }}\right)\right)\end{array}$ & $\begin{array}{l}\text { xpected kur } \\
\left(E\left(\boldsymbol{R}_{\text {kurs }}\right)\right)\end{array}$ & $\begin{array}{c}\text { xpected BBM } \\
\left(E\left(\boldsymbol{R}_{B B M}\right)\right)\end{array}$ & $\begin{array}{c}\text { beta } \\
\text { Inflasi } \\
\left(\boldsymbol{\beta}_{\text {inflasi }}\right) \\
\end{array}$ & $\begin{array}{c}\text { beta } \\
\text { kurs } \\
\left(\boldsymbol{\beta}_{\text {kurs }}\right) \\
\end{array}$ & $\begin{array}{c}\text { beta } \\
\text { BBM } \\
\left(\boldsymbol{\beta}_{B B M}\right) \\
\end{array}$ & \begin{tabular}{|c} 
xpected retur \\
$\left(E\left(\boldsymbol{R}_{\boldsymbol{i}}\right)\right)$ \\
APT
\end{tabular} \\
\hline 1 & AALI & -0.00164 & 0.00565 & 0.00045 & 0.00761 & -0.00739 & -0.067 & 0.476 & 0.311 & 0.00288 \\
\hline 2 & ADHI & 0.03424 & 0.00565 & 0.00045 & 0.00761 & -0.00739 & 0.134 & -3.302 & -0.378 & 0.00342 \\
\hline 3 & ADRO & -0.01097 & 0.00565 & 0.00045 & 0.00761 & -0.00739 & -0.125 & -0.380 & 0.372 & 0.00071 \\
\hline 4 & AKRA & 0.02447 & 0.00565 & 0.00045 & 0.00761 & -0.00739 & -0.277 & -0.619 & -0.027 & 0.00624 \\
\hline 5 & ANTM & -0.00463 & 0.00565 & 0.00045 & 0.00761 & -0.00739 & 0.017 & -0.813 & -0.657 & 0.01254 \\
\hline 6 & ASII & -0.01092 & 0.00565 & 0.00045 & 0.00761 & -0.00739 & -0.032 & -0.853 & -0.153 & 0.00615 \\
\hline 7 & ASRI & 0.01550 & 0.00565 & 0.00045 & 0.00761 & -0.00739 & -0.022 & -3.065 & 0.075 & -0.00122 \\
\hline 8 & BBCA & 0.01084 & 0.00565 & 0.00045 & 0.00761 & -0.00739 & 0.014 & -0.283 & -0.020 & 0.00529 \\
\hline 9 & BBNI & 0.00844 & 0.00565 & 0.00045 & 0.00761 & -0.00739 & -0.016 & -1.263 & -0.065 & 0.00411 \\
\hline 10 & BBRI & 0.01224 & 0.00565 & 0.00045 & 0.00761 & -0.00739 & -0.023 & -1.228 & -0.022 & 0.00365 \\
\hline 11 & BBTN & 0.00577 & 0.00565 & 0.00045 & 0.00761 & -0.00739 & 0.034 & -2.337 & 0.007 & 0.00081 \\
\hline 12 & BMRI & 0.00767 & 0.00565 & 0.00045 & 0.00761 & -0.00739 & 0.012 & -1.985 & 0.047 & 0.00109 \\
\hline 13 & BMTR & 0.01168 & 0.00565 & 0.00045 & 0.00761 & -0.00739 & -0.225 & -0.999 & 0.082 & 0.00380 \\
\hline 14 & BSDE & 0.01984 & 0.00565 & 0.00045 & 0.00761 & -0.00739 & -0.079 & -2.013 & -0.200 & 0.00473 \\
\hline 15 & CPIN & 0.01876 & 0.00565 & 0.00045 & 0.00761 & -0.00739 & -0.065 & -2.085 & -0.190 & 0.00438 \\
\hline 16 & ELSA & 0.01990 & 0.00565 & 0.00045 & 0.00761 & -0.00739 & 0.006 & -1.005 & 0.453 & -0.00226 \\
\hline 17 & GGRM & 0.00825 & 0.00565 & 0.00045 & 0.00761 & -0.00739 & -0.112 & -1.196 & -0.109 & 0.00532 \\
\hline 18 & HMSP & 0.00843 & 0.00565 & 0.00045 & 0.00761 & -0.00739 & 0.024 & -1.345 & -0.139 & 0.00471 \\
\hline 19 & ICBP & 0.02206 & 0.00565 & 0.00045 & 0.00761 & -0.00739 & 0.002 & -0.580 & -0.121 & 0.00609 \\
\hline
\end{tabular}




\begin{tabular}{|c|c|c|c|c|c|c|c|c|c|c|}
\hline No & $\begin{array}{c}\text { Kode } \\
\text { Perusahaan }\end{array}$ & $\begin{array}{c}\text { actual } \\
\text { return } \\
\left(R_{i}\right) \\
\end{array}$ & $\begin{array}{c}\text { free risk } \\
\quad\left(\boldsymbol{R}_{\boldsymbol{f}}\right)\end{array}$ & $\begin{array}{c}\text { expected } \\
\text { inflasi } \\
\left(E\left(R_{\text {inflasi }}\right)\right)\end{array}$ & $\begin{array}{l}\text { xpected kurs } \\
\left(E\left(R_{\text {kurs }}\right)\right)\end{array}$ & $\begin{array}{c}\text { xpected BBM } \\
\left(E\left(R_{B B M}\right)\right)\end{array}$ & $\begin{array}{c}\text { beta } \\
\text { Inflasi } \\
\left(\boldsymbol{\beta}_{\text {inflasi }}\right) \\
\end{array}$ & $\begin{array}{c}\text { beta } \\
\text { kurs } \\
\left(\boldsymbol{\beta}_{\text {kurs }}\right) \\
\end{array}$ & $\begin{array}{c}\text { beta } \\
\text { BBM } \\
\left(\beta_{B B M}\right) \\
\end{array}$ & \begin{tabular}{|c|} 
xpected retur \\
$\left(E\left(R_{i}\right)\right)$ \\
APT \\
\end{tabular} \\
\hline 20 & INCO & -0.00401 & 0.00565 & 0.00045 & 0.00761 & -0.00739 & -0.158 & 0.155 & 0.198 & 0.00420 \\
\hline 21 & INDF & 0.00636 & 0.00565 & 0.00045 & 0.00761 & -0.00739 & 0.001 & -0.606 & -0.070 & 0.00537 \\
\hline 22 & INTP & 0.00352 & 0.00565 & 0.00045 & 0.00761 & -0.00739 & -0.142 & -1.210 & -0.054 & 0.00473 \\
\hline 23 & JSMR & 0.00830 & 0.00565 & 0.00045 & 0.00761 & -0.00739 & -0.080 & -0.889 & -0.243 & 0.00750 \\
\hline 24 & KLBF & 0.00215 & 0.00565 & 0.00045 & 0.00761 & -0.00739 & 0.094 & -1.303 & 0.000 & 0.00261 \\
\hline 25 & LPKR & 0.01518 & 0.00565 & 0.00045 & 0.00761 & -0.00739 & -0.100 & -1.775 & -0.198 & 0.00528 \\
\hline 26 & LPPF & 0.05679 & 0.00565 & 0.00045 & 0.00761 & -0.00739 & -0.033 & -1.494 & -0.128 & 0.00457 \\
\hline 27 & LSIP & 0.00139 & 0.00565 & 0.00045 & 0.00761 & -0.00739 & -0.074 & -0.357 & 0.016 & 0.00513 \\
\hline 28 & $\mathrm{MNCN}$ & 0.02397 & 0.00565 & 0.00045 & 0.00761 & -0.00739 & -0.044 & -1.601 & -0.018 & 0.00298 \\
\hline 29 & MPPA & 0.01213 & 0.00565 & 0.00045 & 0.00761 & -0.00739 & -0.003 & -2.955 & -0.053 & 0.00057 \\
\hline 30 & MYRX & 0.02676 & 0.00565 & 0.00045 & 0.00761 & -0.00739 & 0.037 & -1.139 & -0.132 & 0.00495 \\
\hline 31 & PGAS & -0.00440 & 0.00565 & 0.00045 & 0.00761 & -0.00739 & 0.031 & -1.480 & 0.060 & 0.00181 \\
\hline 32 & PTBA & -0.00910 & 0.00565 & 0.00045 & 0.00761 & -0.00739 & -0.057 & -1.100 & 0.339 & -0.00063 \\
\hline 33 & РТРP & 0.04059 & 0.00565 & 0.00045 & 0.00761 & -0.00739 & -0.028 & -2.344 & -0.235 & 0.00427 \\
\hline 34 & PWON & 0.01012 & 0.00565 & 0.00045 & 0.00761 & -0.00739 & -0.050 & -2.714 & -0.021 & 0.00087 \\
\hline 35 & SCMA & 0.00930 & 0.00565 & 0.00045 & 0.00761 & -0.00739 & -0.120 & -0.970 & 0.136 & 0.00260 \\
\hline 36 & SMGR & 0.00275 & 0.00565 & 0.00045 & 0.00761 & -0.00739 & -0.115 & -0.758 & -0.009 & 0.00489 \\
\hline 37 & SMRA & 0.01978 & 0.00565 & 0.00045 & 0.00761 & -0.00739 & -0.096 & -3.818 & -0.150 & 0.00063 \\
\hline 38 & TLKM & 0.00622 & 0.00565 & 0.00045 & 0.00761 & -0.00739 & 0.066 & -0.675 & -0.026 & 0.00433 \\
\hline 39 & UNTR & -0.00549 & 0.00565 & 0.00045 & 0.00761 & -0.00739 & -0.094 & -0.010 & 0.139 & 0.00431 \\
\hline 40 & UNVR & 0.02077 & 0.00565 & 0.00045 & 0.00761 & -0.00739 & 0.021 & -0.724 & -0.035 & 0.00458 \\
\hline 41 & WIKA & 0.03277 & 0.00565 & 0.00045 & 0.00761 & -0.00739 & 0.039 & -1.584 & -0.252 & 0.00563 \\
\hline
\end{tabular}

Keuntungan yang digambarkan oleh model APT hanya beberapa perusahaan yang mendapatkan keuntungan diatas return yang bebas risiko $\left(R_{f}\right)$, seperti perusahaan AKRA (AKR Corporindo Tbk), ANTM (Aneka Tambang (Persero) Tbk), ASII (Astra International Tbk), ICBP (Indofood CBP Sukses Makmur Tbk), JSMR (Jasa Marga (persero) Tbk).

Saham perusahaan AALI, ADRO, ANTM, ASII, INCO, INTP, KLBF, LSIP, PGAS, PTBA, SMGR, dan UNTR memiliki rata-rata actual return $\left(R_{i}\right)$ yang lebih rendah daripada expected returnnya $\left(E\left(R_{i}\right)\right)$. Hal ini akan memberikan return saham yang lebih kecil dari expected return $\left(E\left(R_{i}\right)\right)$. Hasil ini sama dengan hasil pada model CAPM sebelumnya bahwa kedua belas saham ini kurang cocok untuk dijadikan tempat untuk berinvestasi.

\subsection{Analisis Perbandingan Model CAPM (Capital Asset Pricing Model) dan Model APT (Arbitrage Pricing Theory)}

Perbandingan yang dicari dalam penelitian ini dilihat dari sisi keakuratan model CAPM dan APT dalam memprediksi return saham. Untuk melihat keakuratan Model CAPM dan APT, maka dihitung nilai MAD (Mean Absolute Deviation) untuk model CAPM dan APT menggunakan persamaan (8). Hasil perhitungan MAD dapat dilihat pada tabel 7.

Tabel 7. MAD (Mean Absolute Deviation) Model CAPM dan APT

\begin{tabular}{|r|c|r|r|}
\hline No & Kode Perusahaan & MAD CAPM & MAD APT \\
\hline 1 & AALI & 0.0870 & 0.0836 \\
\hline 2 & ADHI & 0.1171 & 0.1130 \\
\hline 3 & ADRO & 0.0903 & 0.0824 \\
\hline 4 & AKRA & 0.0829 & 0.0931 \\
\hline 5 & ANTM & 0.1076 & 0.1011 \\
\hline
\end{tabular}




\begin{tabular}{|c|c|c|c|}
\hline No & Kode Perusahaan & MAD CAPM & MAD APT \\
\hline 6 & ASII & 0.0679 & 0.0704 \\
\hline 7 & ASRI & 0.0988 & 0.0922 \\
\hline 8 & BBCA & 0.0390 & 0.0440 \\
\hline 9 & BBNI & 0.0580 & 0.0636 \\
\hline 10 & BBRI & 0.0613 & 0.0667 \\
\hline 11 & BBTN & 0.0727 & 0.0688 \\
\hline 12 & BMRI & 0.0559 & 0.0616 \\
\hline 13 & BMTR & 0.1044 & 0.1057 \\
\hline 14 & BSDE & 0.0776 & 0.0788 \\
\hline 15 & CPIN & 0.0967 & 0.0986 \\
\hline 16 & ELSA & 0.1025 & 0.0978 \\
\hline 17 & GGRM & 0.0612 & 0.0589 \\
\hline 18 & HMSP & 0.0692 & 0.0687 \\
\hline 19 & ICBP & 0.0524 & 0.0591 \\
\hline 20 & INCO & 0.1252 & 0.1208 \\
\hline 21 & INDF & 0.0510 & 0.0513 \\
\hline 22 & INTP & 0.0622 & 0.0650 \\
\hline 23 & JSMR & 0.0461 & 0.0456 \\
\hline 24 & KLBF & 0.0587 & 0.0608 \\
\hline 25 & LPKR & 0.0767 & 0.0785 \\
\hline 26 & LPPF & 0.0958 & 0.0956 \\
\hline 27 & LSIP & 0.1118 & 0.1120 \\
\hline 28 & MNCN & 0.1076 & 0.1029 \\
\hline 29 & MPPA & 0.0923 & 0.0885 \\
\hline 30 & MYRX & 0.0756 & 0.0769 \\
\hline 31 & PGAS & 0.0627 & 0.0661 \\
\hline 32 & PTBA & 0.0932 & 0.0889 \\
\hline 33 & PTPP & 0.1110 & 0.1124 \\
\hline 34 & PWON & 0.0961 & 0.0970 \\
\hline 35 & SCMA & 0.0791 & 0.0750 \\
\hline 36 & SMGR & 0.0586 & 0.0614 \\
\hline 37 & SMRA & 0.1160 & 0.0979 \\
\hline 38 & TLKM & 0.0591 & 0.0583 \\
\hline 39 & UNTR & 0.0637 & 0.0624 \\
\hline 40 & UNVR & 0.0450 & 0.0458 \\
\hline 41 & WIKA & 0.0982 & 0.0978 \\
\hline \multicolumn{2}{|r|}{ Average } & 0.0802 & 0.0797 \\
\hline
\end{tabular}

\subsection{Uji-t Dua Sampel Independen pada Data MAD CAPM dan MAD APT}

Hipotesis yang digunakan untuk Uji-t Dua Sampel independen sebagai berikut.

$H_{0}$ : Tidak terdapat perbedaan yang signifikan antara keakuratan CAPM dan keakutratan APT dalam menghitung actual return $\left(R_{i}\right)$.

$H_{1}$ : Terdapat perbedaan yang signifikan antara keakuratan CAPM dan keakuratan APT dalam menghitung actual return $\left(R_{i}\right)$.

Dan dasar pengambilan keputusan dengan $\alpha=5 \%$,

Jika sig.(p) $>0.05$, maka terima $H_{0}$

Jika sig. $(\mathrm{p})<0.05$, maka tolak $H_{0}$

Hasil pengujian dapat dilihat pada tabel 8. Pada kolom Levene's test menunjukkan asumsi kesamaan varians mana yang akan digunakan pada pengambilan keputusan pada Uji-t Sampel Independen. Nilai signifikansi pada kolom Levene's test sebesar 0.356 yang berarti bahwa asumsi yang digunakan adalah equal variances assumed atau varians diasumsikan sama besar. Dengan demikian digunakan signifikansi Uji-t Sampel Independen dengan asumsi varians sama besar atau equal variances assumed. 
Tabel 8. Independent Sample Test

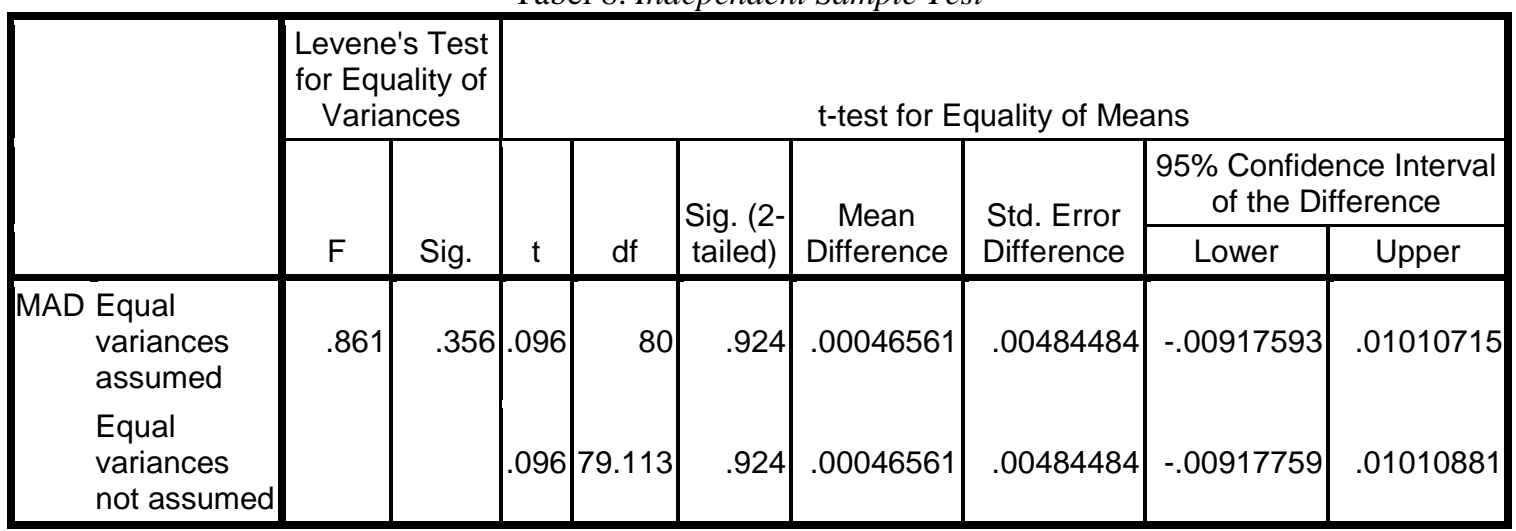

Nilai siginifikansi Uji-t Sampel Independen pada asumsi equal variances assumed sebesar 0.924 yang lebih besar dari $5 \%$ atau 0.05 , yang berarti menerima hipotesis awal $\left(H_{0}\right)$, yaitu "Tidak terdapat perbedaan yang signifikan antara keakuratan CAPM dan keakuratan APT dalam menghitung actual return $\left(R_{i}\right)$ ".

Pada penelitian ini, kedua model dapat dikatakan sama saja dalam pengestimasiannya, karena tidak memberikan perbedaan keakuratan yang signifikan/besar, karena dari hasil penelitian ini perbedaan deviasi dari kedua model sangat kecil. Munculnya perbedaan yang bervariasi hasil penelitian mengenai keakuratan model CAPM dan APT menurut penulis penyebabnya adalah gangguan data yang muncul pada data historical yang digunakan. Karena model CAPM dan APT memiliki unsur yang sangat penting, yaitu beta $(\beta)$ sebagai pengukur return terhadap faktor-faktor yang dianggap memengaruhi, maka beta $(\beta)$ ini harus bersifat BLUE (Best Linear Unbiased Estimator).

Jika error didalam beta $(\beta)$ semakin besar, semakin jauh juga keakuratan dari model tersebut dalam menghitung/memprediksi actual return $\left(R_{i}\right)$ saham. Disamping itu, data-data yang digunakan dalam membangun beta $(\beta)$ pun tak luput dari gangguan-gangguan yang menyebabkan data memiliki error, seperti masalah kenormalan, ragam/varians yang tidak homogen, adanya korelasi antar variabel bebas dan korelasi antara periode pengamatan dan periode sebelumnya, dan lainnya.

\section{Kesimpulan}

Kesimpulan yang diperoleh dari hasil penelitian ini adalah "tidak adanya perbedaan yang signifikan model CAPM dan model APT dalam memprediksi actual return saham". Hal ini didukung oleh dua poin, yaitu :

1. Dilihat dari nilai MAD (Mean Absolute Deviation) dari kedua model, rata-rata nilai MAD CAPM sebesar 0.0802 dan nilai MAD APT sebesar 0.0797. Kedua nilai tersebut hanya selisih 0.0005 .

2. Berdasarkan hasil Uji-t Sampel independen, nilai signifikansi sebesar $0.924>0.05$ ini berarti terima $H_{0}$ yang berarti tidak terdapat perbedaan yang signifikan antara keakuratan CAPM dan keakuratan APT dalam menghitung actual return pada saham yang terdaftar pada LQ45.

\section{Daftar Pustaka}

[1] Jogyanto, 2003. Teori Portofolio dan Analisis Investasi Edisi 3. BPFE-Yogyakarta. Yogyakarta.

[2] Lemiyana, 2015. Analisis Model CAPM dan APT dalam Memprediksi Tingkat Return Harga Saham Syariah (Studi Kasus di Jakarta Islamic Index). Jurnal I-Finance 1(1): 1-20.

[3] Husnan, S. 2015. Dasar-Dasar Teori Portofolio \& Analisis Sekuritas Edisi Kelima. UPP STIM YKPN. Yogyakarta. 
[4] Cherie, I., Darminto, dan Farah, D. 2014. Penerapan Metode CAPM (Capital Asset Pricing Model) untuk Menentukan Pilihan Investasi pada Saham (Studi pada Perusahaan Sektor Consumer Good Industry di Bursa Efek Indonesia Periode 2010-2012. Jurnal Administrasi Bisnis (JAB). 13(2) : 1-9.

[5] Maftuhah, H. 2014. Perbandingan Metode CAPM dan APT Dalam Menghitung Return Saham JII (Skripsi). Jakarta : UIN Syarif Hidayatullah.

[6] Ahmad, K. 2004. Dasar-Dasar Manajemen Investasi dan Portofolio Edisi revisi. Rineka Cipta Jakarta.

[7] Hatidja, D. 2006. Analisis Regresi. Jurusan Matematika FMIPA Universitas Sam Ratulangi. Manado.

[8] Myers, R. H. 1990. Clasiccal and Modern Regression with Applications Second Edition. PWSKENT Publishing Company. Boston.

[9] Pongoh, F. 2010. Perbandingan Analisis Regresi Berganda Tanpa dan Dengan Pengujian Asumsi Klasik : Studi Kasus Hubungan Berat dengan Panjang, Tinggi, Panjang Sirip pada Ikan Mas (Cyprinus Carpio L.) dan Ikan Mujair (Oreochromis Mossambicus) (Skripsi). Manado : Universitas Sam Ratulangi.

[10] Uyanto, S. S. 2009. Pedoman Analisis Data dengan SPSS Edisi 3. Graha Ilmu. Yogyakarta. 